\title{
Doctor-patient communication in radiology: a great opportunity for future radiology
}

\section{La comunicazione verbale medico-paziente in radiologia: una grande opportunità nel futuro della radiologia}

\section{Bazzocchi}

Institute of Diagnostic Radiology, University of Udine, P.le Santa Maria della Misericordia 15, 33100 Udine, Italy Correspondence to: M. Bazzocchi, Tel.: +39-0432-559266, Fax: +39-0432-559867, e-mail: bazzocchi.massimo@aoud.sanita.fvg.it

Received: 1 September 2011 / Accepted: 16 September 2011 / Published online: 20 March 2012

(C) Springer-Verlag 2012

\begin{abstract}
This text discusses several aspects of doctor-patient communication in radiology, including the origins, advantages, and ethical and legal aspects. Over the last 10 years, radiologists have assumed increasing responsibilities towards patients and society. Patients, who are becoming better informed and more aware about medical issues, have a right to be given a timely diagnosis and want to receive as much information as possible from the radiologist. This has implications for several levels of everyday radiological practice, including the organisation of work, legal and ethical aspects and radiologist training. Better interaction with the patient helps to build a closer, more trusting, relationship with the result that the radiologist will be more motivated in his or her work. Until now, radiologists were not adequately trained to communicate the diagnosis directly and verbally to patients, especially when the diagnosis was unfavourable. It is important to emphasise the need for more specific and practical training in this respect, which is indispensable for future developments of the discipline.
\end{abstract}

Keywords Communication · Radiology $\cdot$ Physician-patient relations

\section{Riassunto}

Nel presente testo vengono discussi gli aspetti relativi alla comunicazione medico-paziente in radiologia: le origini, i vantaggi, gli aspetti etici e legali. Il radiologo sta assumendo in questi ultimi decenni responsabilità sempre maggiori nei confronti del paziente e della società. Il paziente, sempre più informato e consapevole, ha diritto di conoscere il prima possibile la diagnosi e desidera avere dal radiologo quante più informazioni possibili. Questo implica tutta una serie di ripercussioni sulla pratica professionale di tipo organizzativo, legale, etico e formativo. Una migliore interrelazione con il paziente contribuisce a edificare un rapporto di fiducia più intimo con il medico radiologo che risulterà più motivato nell'espletamento delle sue funzioni. Finora il radiologo non risulta sufficientemente preparato per fornire la diagnosi direttamente e verbalmente al paziente, specie se si tratta di diagnosi sfavorevoli. Viene enfatizzata la necessità di una preparazione più specifica ed eminentemente pratica, imprescindibile negli sviluppi futuri della disciplina.

Parole chiave Comunicazione $\cdot$ Radiologia $\cdot$ Rapporto medico-paziente

\section{Introduction}

Genesis 1(3, 4): And God said "Let there be light..."

The first verses of the Bible state that God "said" and that each phase of creation essentially came in to being through

\section{Introduzione}

Genesi 1(3,4): E Dio disse "Sia la luce..."

Nei primi versi della Bibbia si legge che Dio "disse" e che alla sua parola sostanzialmente fecero seguito le diverse 
God's word. When God created Adam "in his own image and likeness", Adam is implicitly given the gift of speech. In the Greek version of the Bible, "word" corresponds to the term logos. Plato (427-347 B.C.) mostly uses the term in the meaning of speech and reasoning but with a transcendental connotation .... The prologue of the fourth gospel (John 1.1-18) presents the figure of the Word (Logos) as he who "was in the beginning", who "was with God" and "was God" (John 1.1). I therefore like to think that speech - the word - is the divine element within humans.

Speech is therefore also a vital component of the radiologist's profession, and specifically in the field of doctorpatient communication. And yet, most meetings on communication deal with issues concerning the written report, nowadays structured and undoubtedly evolved compared with the past - partly the result of information technology but nonetheless still a written report. There are good reasons to believe that written communication cannot be considered sufficient and that verbal communication will become increasingly central to the development of the modern radiologist [1-3].

If we look at the patient's healthcare journey from the time of the request for a radiological investigation to when the report and images are delivered, we find a number of situations in which any form of communication other than verbal is insufficient. The patient's difficulties were also been highlighted in a research project of the Italian census institute Censis at a meeting held in Rome in 2007. This survey found that despite the wealth of health information accessible through the thousands of media available today, only $22 \%$ of users consider themselves to be adequately informed [4].

Let us consider the different steps:

1. At the outset, when booking the investigation, the patient will wonder - often encouraged by the prescribing physician - whether the examination ordered is the most appropriate for his or her problem. In these situations, the booking centre [Centro Unico di Prenotazione (CUP)] is often inadequate, and the online information leaflets tend to be too general and are easily misunderstood.

2. At the time of the radiological examination, very often the patient does not see the radiologist, but only the nonphysician health professional. One of the most tangible problems of modern radiology - with its dramatic technological progress - lies in the radiologist's loss of visibility (increasingly faceless, having no contact with the patient), an aspect well captured by Glazer and RuizWibbelsmann in their description of the invisible radiologist working behind the machines or even in distant offices [3]. This problem affects the public sector and large facilities more than it does the private sector and small tappe della creazione. Quando Dio creò Adamo, "a propria immagine e somiglianza”, Adamo avrà implicitamente il dono della parola. Nella versione greca della Bibbia viene impiegato per "parola" il termine lògos. Platone (427-347 a.C.) utilizza il termine prevalentemente secondo i significati di "discorso" e di "ragione", designandovi però qualcosa di trascendente... Il prologo del IV Vangelo (Giovanni 1,1-18) presenta la figura del Verbo (Logos) come colui che "era in principio", che "era presso Dio" ed "era Dio" (Giovanni 1,1).

Dunque mi piace pensare che sia proprio la parola l'elemento divino che realmente caratterizza l'uomo. Così non si può non pensare che la "parola" non assuma un ruolo determinante nella professione del radiologo, e nella fattispecie nell'ambito della comunicazione medico-paziente. Eppure la gran parte dei convegni di comunicazione si preoccupano di trattare le problematiche del referto scritto, ora strutturato e indubbiamente evoluto, grazie anche allo sviluppo dell'informatica, rispetto al passato, ma pur sempre scritto. Esistono fondati motivi per ritenere che non ci si possa accontentare della sola comunicazione scritta, ma che la comunicazione verbale vada a rivestire un ruolo determinante nello sviluppo del radiologo moderno [1-3].

Se analizziamo il percorso che il paziente compie dal momento in cui viene formulata la richiesta di un'indagine radiologica alla consegna del referto e delle immagini relative esistono tutta una serie di situazioni nelle quali le forme di comunicazione diverse dalla parola, ovvero dalla comunicazione verbale, non sono sufficienti. Tale disagio del paziente è stato anche sottolineato da una ricerca del Censis, settore ricerca biomedica, in un convegno tenutosi a Roma nel 2007, dove si è evidenziato che, a fronte di una massa enorme di informazioni sanitarie che pervengono attraverso i mille veicoli mediatici oggi a disposizione, solamente il $22 \%$ degli utenti si ritiene sufficientemente informato [4].

Analizziamo i diversi punti:

1. Il paziente già nella fase di prenotazione si interroga, spesso sollecitato dal medico prescrivente, se la prescrizione di indagine a lui fornita sia la migliore per il suo problema. Di solito in tali situazioni l'ufficio preposto (Centro Unico di Prenotazione, CUP) è spesso inadeguato e le informazioni informatizzate si rivelano perlopiù generiche e insufficienti, nonché mal comprese.

2. Il paziente, durante l'esecuzione delle indagini di diagnostica per immagini, molto spesso non vede il medico radiologo, ma solamente gli operatori sanitari non medici. Raccontava il giornalista Tiziano Terzani che grazie ad un'attenta diagnosi operata da un medico radiologo newyorchese, durante uno dei suoi tanti ricoveri per problematiche oncologiche, ne ricavò un cospicuo giovamento in termini di vita sia qualitativamente che quantitativamente, ma lo stesso affermava di non aver potuto manifestare la propria riconoscenza per non aver mai avuto l'occasione di incontrare e vedere il radiologo. Una delle problematiche più reali della radiologia moderna consiste a fronte di uno sviluppo tecnologico eccezionale in una perdita della visibilità del radiologo 
practices and clearly does not apply to imaging techniques performed by the radiologists themselves, such as ultrasound, breast imaging, biopsy techniques and interventional procedures.

3. The written report, whether structured or otherwise, is mostly incomprehensible to patients, even though the situation has considerably improved and radiologists have stopped using purposefully cryptic and indecipherable terms. On the other hand, reports often refer to international classifications [Breast Imaging Reporting and Data System (BI-RADS) [5], or the Bosniak classification for renal masses [6], etc.], which may be useful to the doctor but are no less obscure and unsettling for the patient. Even though the shift towards an increasingly quantitative and epicritic - as opposed to descriptive and qualitative - radiology is a prerequisite for providing objective, measurable and comparable data, it does not help improve the patient's understanding of the purely technical content. The problem cannot be minimised by merely formal acts, as stated by Tamburrini [7] (signed consent $=$ informed consent). It requires a careful analysis, such as the one that led Glazer and Ruiz-Wibbelsmann to advocate a patient-centred, personalised radiology and a new culture of improved healthcare, where radiology is no longer just a service [1, 3]. Still, Tamburrini [7] warns us of the possible dichotomy between technology (radiologist increasingly expert and knowledgeable about technology) and communication (less knowledgeable but a better communicator). On the other hand, we are more and more coming to realise that increasing complexity does not mean improving healthcare. The issue of complexity, particularly felt in the Western world due to the pressure of many stakeholders (electromedical, pharmaceutical industry, physicians themselves, etc.), was well analysed and taken apart by Atul Gawande in his special lecture at Radiological Society of North America (RSNA) 2010 in Chicago titled "Real reform: facing the complexity of health care" [8]. Gawande demonstrated that complexity in health systems leads to ineptitude, which, though not ignorance, is equally as serious and counterproductive ("The checklist manifesto. How to get things right") [9].

4. Often, the diagnostic examination is inconclusive, and a specific specialist needs to be consulted to complete the diagnosis or establish the most appropriate treatment. This aspect is accommodated for in the structured report and is an indication of a new role of responsibility [10]. But who is to take on this role of gatekeeper? Is it enough to indicate it in the structured report? Often, the patient feels lost and confused, particularly when faced with a diagnosis perceived as fatal, and it becomes extremely difficult to find the way through the diagnostic and thera- (radiologo sempre più faceless, senza faccia, senza contatto con il paziente), aspetto ben descritto da Glazer e Ruiz-Wibbelsmann nel loro "radiologo invisibile" che opera dietro le macchine o addirittura lontano [3]. Tale problema investe di più il settore pubblico e le grosse organizzazioni, meno quello privato e le piccole realtà. Naturalmente esistono eccezioni rappresentate dalle tecniche gestite direttamente dal radiologo quali l'ecografia, la diagnostica senologica, le tecniche bioptiche e la radiologia interventistica.

3. Il referto scritto, strutturato o meno, è perlopiù in larga parte incomprensibile al paziente, anche se, oggi, le cose sono decisamente migliorate rispetto al passato e si è abbandonata da tempo quella terminologia scritta che era appositamente criptica per risultare indecifrabile. In compenso oggi molto spesso adottiamo delle classificazioni internazionali (Breast Imaging Reporting Data System, BI-RADS [5], o quella di Bosniak per le masse renali [6], ecc.) che risultano altrettanto oscure e inquietanti per il paziente, anche se straordinariamente utili per il medico. Il passaggio ad una radiologia sempre più quantitativa ed epicritica, invece che descrittiva e qualitativa, se da un lato rappresenta una necessità, al fine di fornire dati oggettivi misurabili e confrontabili nel tempo, dall'altro non riduce l'incomprensione che il paziente nutre per $i$ suoi contenuti squisitamente tecnici. Il problema non si riduce con dei semplici atti formali, come ribadisce Oscar Tamburrini [7] (consenso firmato=consenso informato), ma da un'attenta analisi che portano Gary Glazer e Julie Ruiz-Wibbelsmann a sostenere la necessità di una radiologia centrata sul paziente, personalizzata e quindi a sostenere il dovere di creare una nuova cultura che condizioni il sistema sanitario, dove la radiologia non sia mero servizio [1, 3]. Sempre Tamburrini [7] ci mette in guardia sulla possibile dicotomia fra tecnologia (radiologo sempre più ricco di conoscenze tecnologiche e informato) e comunicazione (radiologo più comunicatore, ma meno informato). D'altra parte oggi avanza sempre di più il convincimento che aumentare la complessità non significhi migliorare l'assistenza. Tale problema, presente nel mondo occidentale spesso per la spinta di numerosi stake-holders (industria elettromedicale, farmaceutica, gli stessi medici ecc.), è stato ben analizzato e smontato da Atul Gawande nella special lecture al RSNA 2010 di Chicago: "Real reform: facing the complexity of health care" [8]. Gawande dimostra come la complessità nel sistema sanitario porti all'inettitudine, che non è ignoranza, ma è altrettanto grave e controproducente dell'ignoranza (The checklist Manifesto. How to get Things Right) [9].

4. Molto spesso, inoltre, l'indagine diagnostica non è conclusiva, ma è da richiedere la consulenza di un determinato specialista per completare la diagnosi o per impostare la terapia più corretta. Tale aspetto è previsto dal referto strutturato ed è indice di un nuovo ruolo di responsabilità [10]. Ma chi si assume realmente il ruolo di gate-keeper? È sufficiente indicarlo nel referto strut- 
peutic journey. As a result, the patient needs to be guided, almost taken by the hand and led in the right direction through this personal hell, just as Virgil led Dante through the circles of hell in the Divine Comedy.

In the final analysis, many questions and issues will determine our need to communicate and dictate what, when and how we should do so.

\section{Why communicate?}

\section{Users' point of view}

"...the best interest of the patient is the only interest to be considered..."

William J. Mayo, 1910 [11]

"...is it not really the patient we are obligated to serve above all others?"

Robert S. Sherman [12]

The ethical principle of an increasingly patient-centred medicine and heightened patient awareness that allows patients to make guided but autonomous decisions has been established by the latest versions of the 1998 Italian Code of Ethics [13]. The concept had been expressed by the remarkable intuition of Dr. Mayo more than a century ago and then restated by Robert Sherman more than 50 years ago in relation to the radiologist being considered "the doctor's doctor" [14]; that is, the professional who was meant to serve another professional and report to that professional alone. Things have changed in half a century. Firstly, there has been an increase in the demand for healthcare, health information and the public's desire to refer directly to the diagnostician, including the radiologist. In this scenario, the self-referred patient enters an unwritten contract with the radiologist and demands that the response be given to himself/ herself or to a trusted person.

In parallel, a culture of prevention has developed, which in radiology has translated into screening mammography. In this case, the subject is a healthy individual in whom the test and the wait for the answer create a state of anxiety; the subject wants to know the outcome of the test as soon as possible, even though the most likely result is negative. In this regard, the Mammography Quality Standards Act (MQSA) [15], introduced into US law on 27 October 1992, strongly recommended communicating as soon as possible any doubtful or suspicious result from screening mammography. The concern at the time perhaps had more to do with insurance problems than ethical issues, as it emerged that several malpractice lawsuits had been filed turato? Molto spesso il paziente è spaesato e confuso soprattutto di fronte ad una diagnosi che venga percepita come infausta e quindi in estrema difficoltà nel trovare la via per proseguire il suo iter diagnostico e terapeutico. Quindi si intravede la reale necessità che il paziente venga guidato, quasi preso per mano, e condotto nella giusta direzione come Virgilio guidava Dante nella Divina Commedia attraverso $i$ gironi infernali, dato che il paziente in determinate circostanze vive il suo personale inferno in quel momento.

In ultima analisi sono molti gli interrogativi e le problematiche che entrano in gioco, che giustificano il perché comunicare, e richiedono che cosa e quando comunicare, come comunicare.

\section{Perché comunicare}

Il punto di vista dell'utenza

“... the best interest of the patient is the only interest to be considered..." William J. Mayo, 1910 [11]

"... is it not really the patient we are obligated to serve above all others?"

Robert S. Sherman [12]

Il concetto etico di una medicina sempre più pazientocentrica e orientata verso la consapevolezza del paziente in grado di operare scelte guidate ma autonome, è sancito dall'ultima versione del Codice Etico nazionale del 1998 [13]. Tale concetto era già stato espresso dall'incredibile intuizione del dott. Mayo di oltre 100 anni fa, e ribadito da Robert Sherman oltre 50 anni fa a proposito della professione del radiologo, per lungo tempo considerato "il dottore dei dottori" [14], ovvero il professionista che doveva servire un altro professionista e riferire a lui solo. Le cose sono cambiate in mezzo secolo. Innanzi tutto è aumentata la domanda di salute, l'informazione in ambito sanitario e il desiderio della persona di rivolgersi direttamente allo specialista diagnosta, radiologo compreso. In tal modo il paziente self-referred stipula un contratto non scritto con il radiologo e esige la risposta per se medesimo o per una persona di sua fiducia.

Parallelamente è nata la cultura della prevenzione, che in ambito radiologico si è tradotta con la mammografia di screening. In tal caso il soggetto è un paziente sano in cui viene creato uno stato di ansietà attraverso l'esecuzione di un test e l'attesa della sua risposta; il soggetto desidera conoscere quanto prima il risultato della sua indagine, anche se le aspettative più probabili sono rappresentate dalla negatività del test. In relazione a questo The Mammography Quality Standars Act (MQSA) [15], introdotto in una legge americana il 27 ottobre 1992, suggeriva con forza il dovere di comunicare nel più breve tempo possibile alle interessate l'evenienza di un risultato dubbio o sospetto 
because women claimed they had not been duly informed of a suspicious result [16]. Apart from insurance issues, the patient is always in a deep state of anxiety when awaiting a diagnosis. This feeling is illustrated by Leonard Berlin in an article with the self-explanatory title: "Communicating results of all radiologic examinations directly to patients: has the time come"'? [17-19]. Berlin asks whether it would be possible to reduce the patient's anxiety if she were to receive the results directly from the radiologist as soon as possible [17]. A survey conducted in 1993 demonstrated that $75 \%$ of referring physicians and $90 \%$ of radiologists were comfortable with radiologists communicating the test results directly to the patient, even though only $28 \%$ of clinicians and $33 \%$ of radiologists were willing to have the radiologist communicate the result if the test was positive [20]. Other surveys in 1995 found that $94 \%$ of patients believed that the radiologist should give them the diagnosis directly at the time of the examination [21, 22]. In 1998, Ragavendra et al. [23] found that $84 \%$ of patients undergoing sonography preferred receiving the results directly from the radiologist. A 1994 study on the preferences of women undergoing mammography revealed that $90 \%$ of respondents agreed that the radiologist should give them the results directly on site [24]. This desire is confirmed by a public health journal with regard to young women affected by breast cancer and their desire to be informed of their fate [25]. In the same year, the concept was restated that information and a more direct involvement of the patient in decision making improved patient satisfaction as well as outcome, as it had a positive impact on functional recovery and quality of life and increased acceptance of oncological therapies [26]. More recently, Basu et al. emphasised that patients' priority is to have results communicated to them as soon as possible, regardless of which physician does this [27]. No less than $35 \%$ of patients preferred receiving abnormal results by phone.

Therefore, the demand for more, better, direct and faster communication is present throughout the Western world, including in Italy, where the media often highlight the poor communication skills of health professionals [28]. There may be different aspirations in Europe depending on the social culture. In eastern Europe, particularly in Russia, the practice of informing the patient is less widespread, whereas Lorch and Scherer report that in Germany, $48 \%$ of patients want to be informed by their radiologist and $58 \%$ by their physician; $75 \%$ would prefer to be told of the result within $30 \mathrm{~min}$ of the test and therefore by the radiologist [29]. In the meantime Italian Hospital Trusts have set up new public relations offices [Uffici di Relazione con il Pubblico (URP)], which, however, fail to go to the root of the problem which is primarily one of doctor-patient relations. della mammografia di screening. La preoccupazione allora era forse motivata più che da motivi etici da problemi assicurativi, perché emergeva che diverse cause legali erano state intraprese perché le donne affermavano di non essere state debitamente informate del risultato, quando sospetto [16]. A prescindere dagli aspetti assicurativi comunque il paziente nutre un profondo stato d'ansia quando è in attesa di una diagnosi. Tale sensazione viene descritta con alcuni significativi esempi da Leonard Berlin in un articolo dal titolo esplicativo: Communicating results of all radiologic examinationts directly to patients: has the time come? [17-19]. Berlin si domanda se vi sia la possibilità di ridurre lo stato d'ansia nel caso il paziente riceva direttamente dal radiologo la risposta nel più breve tempo possibile [17]. Un'inchiesta effettuata nel 1993 dimostrò che il 75\% dei medici prescrittori e il $90 \%$ dei radiologi erano d'accordo nel favorire la comunicazione diretta della diagnosi al paziente da parte del radiologo, anche se soltanto il $28 \%$ dei clinici e il 33\% dei radiologi stimava che il radiologo dovesse fornire il risultato qualora fosse stato positivo [20]. Altre inchieste condotte nel 1995 trovarono che il 94\% dei pazienti pensavano fosse il caso che il radiologo spiegasse loro direttamente e subito la diagnosi [21, 22]. Nel 1998 Raganvedra et al. [23] trovarono che l'84\% dei pazienti dopo un esame ecografico preferiva avere la risposta direttamente dal radiologo. Un'inchiesta eseguita nel 1994 sui desideri di donne sottoposte a mammografia dimostrò che più del $90 \%$ delle intervistate era d'accordo sul fatto che il radiologo dovesse fornire la diagnosi direttamente alle interessate [24]. La stessa aspirazione viene sancita su di una rivista di sanità pubblica a proposito della volontà di conoscere il proprio destino da parte di giovani donne affette da carcinoma mammario [25]. Nello stesso anno viene ribadito il concetto che già l'esperienza di molti aveva suggerito, che una migliore informazione e un più diretto coinvolgimento della paziente nelle decisioni dimostrava avere un effetto positivo sia nella soddisfazione della donna, sia nel suo out-come, ovvero come ricaduta positiva nel recupero funzionale e sulla qualità di vita, anche per una migliore accettazione delle terapie oncologiche [26]. Più recentemente Basu et al. [27] mettono in luce che l'esigenza principale del paziente è quella di avere la comunicazione della risposta nel più breve tempo possibile, anche indipendentemente dal medico che la fornisce. Addirittura il 35\% degli intervistati preferirebbe avere le risposte patologiche per telefono piuttosto che di persona.

La richiesta quindi di una maggiore, migliore, più diretta e più rapida comunicazione è presente in tutto il mondo occidentale, nella fattispecie in Italia, dove i media spesso mettono in evidenza le carenze di capacità di comunicazione con il pubblico [28]. Ci possono essere differenze di desiderata in Europa dipendentemente dalla cultura sociale. Nell'est europeo, in particolare in Russia, la pratica di informare il paziente è meno diffusa, mentre in Germania Lorch e Scherer [29] riportano che il 48\% dei pazienti vorrebbe essere informato dal radiologo, il 58\% preferirebbe il proprio medico, ma ben il $75 \%$ dei soggetti vorrebbe avere 
Professionals' point of view

"The single biggest problem in communication is the illusion that it has taken place." George Bernard Shaw

"Because the responsibilities of radiologists have expanded, it seems possible that radiologists may eventually be charged with directly informing patients of the results of procedures as well." Leonard Berlin [14]

Communicating is not easy and, as Berlin stresses [14], taking on new responsibilities implies knowing how to communicate directly with the patient. This new function of the radiologist is in itself a new duty. There are good practical reasons to communicate and improve one's communication skills. Many malpractice suits, in the United States, Italy and Europe, stem from faulty communication, noncommunication or inadequate communication. Berlin recounts a paradigmatic case [30]: On 6 June 2008 the Virginia Supreme Court [31] rendered a decision against a radiologist on the basis of negligence for not having communicated to a patient the presence of a deep vein thrombosis of the leg, or rather, the need to start anticoagulation therapy immediately to prevent pulmonary embolism. A series of tragic circumstances caused the death of the woman who developed fatal pulmonary embolism $48 \mathrm{~h}$ later. The radiologist tried to phone the referring physician but there was no answer (it was Friday afternoon). He then sent a fax, which the referring physician saw but did not read, and, finally, the pulmonary embolism occurred on a Sunday. The sentence emphasises the need to inform patients of their state of health, especially when they are potentially in danger. The radiologist in such cases is obliged to give exhaustive information directly to the patient. Over time, there has been an increase in malpractice lawsuits for faulty communication; in the USA in only 5 years between 1985 and 1990 they have grown by $15 \%$ [32]. An article by Levinson reports that in 1994, 80\% of malpractice lawsuits in the USA were based on communication problems [33]; in 2004, Fernald et al. reported that communication errors were present in $70 \%$ of reports [34].

On the other hand, Italian law regards the doctor-patient relation as a contract to be honoured. This applies, as Adriano Fileni states [35], both to outpatients [30] and inpatients, which means the patient must be satisfied even in terms of direct information. Extending the professional contract to inpatients would in itself necessitate careful consideration and discussion, as communication issues may be even more complex in the case of inpatients and closely related to their state of health and ability to relate. la risposta entro 30 minuti dall'indagine e quindi dal radiologo. Nel frattempo le aziende ospedaliere hanno creato nuovi uffici di relazione con il pubblico (URP) che però non vanno alla radice del problema, che è di squisita natura rapporto medico-paziente.

Il punto di vista professionale

"The single biggest problem in communication is the illusion that it has taken place."

George Bernard Shaw

"Because the responsabilities of radiologists have expanded it seems possible that radiologists may eventually be charged with directly informing patients of the results of procedures as well" Leonard Berlin [14]

Non è facile comunicare e, come sottolinea Berlin [14], l'assunzione di nuove responsabilità implica il dovere di sapere comunicare direttamente al paziente. Tale funzione o nuova prerogativa del radiologo è, essa stessa, "una nuova responsabilità”. Ci sono dei buoni motivi pratici per comunicare e migliorare le proprie capacità comunicative. Molte cause legali, sia negli Stati Uniti che in Italia ed in Europa hanno alla loro base un difetto di comunicazione, una mancata comunicazione o una comunicazione insufficiente. Berlin riporta una sentenza paradigmatica [30]. Il 6 giugno 2008 la suprema corte dello stato della Virginia [31] pronunciò una sentenza sfavorevole al radiologo per negligenza per non avere comunicato a una paziente la presenza di una flebotrombosi dell'arto inferiore o meglio la necessità di intraprendere immediatamente un trattamento anticoagulante per evitare l'embolia polmonare. Un insieme di tragiche circostanze portarono a morte la donna che dopo 48 ore ebbe un'embolia polmonare mortale: il radiologo cercò al telefono il medico curante che non rispose (era un venerdì pomeriggio); inviò un fax che il medico curante vide, ma non lesse, ed infine capitò davvero l'embolia e per giunta nel giorno festivo. La sentenza enfatizza la necessità di informare il paziente del suo stato di salute soprattutto quando è in potenziale pericolo per la sua salute. Il radiologo in questi casi è tenuto a dare debita ed esaustiva comunicazione direttamente al paziente. Nel tempo le cause per un'incorretta comunicazione sono cresciute; negli USA in appena 5 anni dal 1985 al 1990 del 15\% [32]. Un altro articolo di Levinson riporta che, nel 1994, l'80\% delle cause per malpractice negli USA si fondavano su difetti di comunicazione [33] e, nel 2004, Fernald et al. [34] riportano che errori di comunicazione erano presenti nel $70 \%$ dei referti.

D'altra parte oggi la legislazione italiana vede nel rapporto medico paziente un rapporto di tipo contrattuale, che va onorato, e questo vale, come afferma Adriano Fileni [35], non solo nei confronti del paziente esterno [30], ma anche del ricoverato e questo significa che il paziente deve essere soddisfatto anche in termini di informazione diretta. Il contratto professionale esteso ai pazienti ricoverati 
Moreover, many patients often file lawsuits for not having been, in their opinion, informed or listened to or because they feel they have been treated in a cold and detached manner [36]. The situation is worse if there is also some error that, once disclosed, is not acknowledged by the doctor.

"The only unforgivable sin is to conceal errors" Karl Popper [37]

It is a fact that physicians often tend to conceal their errors, whereas patients think that physicians should never make mistakes (and the media reinforce such a conviction). On the other hand, radiological error is unavoidable in $2-20 \%$ of cases $[17,38-40]$. Only by being clearly informed of the potential for error can patients be made to understand human fallibility and the rate of error inherent in the radiological modality. In addition, patients appreciate this sincerity. This way, it is possible to build that construct of complicity and understanding that forms the bond of empathy between doctor and patient. Empathy, a word coined by Bradford Tichener in 1909, could be simply defined as "putting oneself in someone else's shoes". Antonio Damasio [41] states that effective communication (empathetic) is the most crucial personal asset: it allows us to coordinate all our other skills, such as observing and solving problems; it changes the quality of the relationship, preventing dysfunction, misunderstandings, errors and waste of time and resources. When creating an empathetic communication with the patient, the doctor is aware of the patient's needs, is more concentrated and makes fewer mistakes; at the same time, the patient appreciates the doctor's difficulties.

\section{What and when to communicate}

"You have two ears and one mouth, which means you should listen twice as much as you speak ..."

Saint Jerome

“... in situations of uncertainty the patient's anxiety is reduced merely by talking, even if this is not conclusive."

Anonymous

A willingness to listen to the patient is the first step towards correct verbal communication, and just uttering simple words in an understanding manner reduces anxiety and creates a proactive problem-solving atmosphere. However, although often useful, this it is not always sufficient. Several authors have considered the content and "whether to tell", "when to tell", and "how to tell". Smith and Gunderman [42] address the issue by discussing four approaches: (1) da solo richiederebbe un'attenta riflessione e discussione, dato che per tali pazienti le problematiche di comunicazione possono essere ancora più complesse, fortemente legate anche allo stato di salute del paziente e alla sua capacità di interrelazione.

Molti pazienti inoltre spesso ricorrono legalmente verso il medico per non essere stati, a loro dire, informati né ascoltati su loro richiesta oppure perché si sono sentiti trattati in modo freddo e distaccato [36]. La cosa si aggrava se c'è anche un errore che, diventato palese, non viene riconosciuto dal medico.

"L'unico errore imperdonabile è nascondere un errore" Karl Popper [37]

$\grave{E}$ un dato di fatto che spesso $i$ medici tendono a celare $i$ propri errori, mentre $i$ pazienti pensano che $i$ medici non dovrebbero mai sbagliare (e i media rafforzano tale convinzione). D'altra parte l'errore radiologico è inevitabile dal $2 \%$ al $20 \%$ [17, 38-40]. È evidente quindi che solamente con un'adeguata comunicazione al paziente della potenziale possibilità di errore, possa venire recepita la fallibilità umana, nonché compresa la percentuale di incertezza insita nel metodo, e apprezzata la sincerità. In tal modo è possibile edificare quel edificio di complicità e comprensione che crea il legame empatico fra medico e paziente. L'empatia, parola coniata da Bradford Tichener nel 1909, potrebbe essere semplicemente definita come "mettersi nei panni dell'altro". Antonio Damasio [41] afferma che una comunicazione efficace (empatica) costituisce la più cruciale delle risorse personali e consente di coordinare tutte le altre capacità che si possiedono, come osservare e risolvere problemi; trasforma la qualità della relazione impedendo disfunzioni, incomprensioni, errori, spreco di tempo e di risorse. Creando una comunicazione empatica il medico avverte le necessità del paziente, è più concentrato e fa meno errori e contestualmente il paziente comprende le difficoltà del medico.

\section{Che cosa e quando comunicare}

"Hai due orecchie e una bocca, ciò significa che devi ascoltare il doppio delle parole che pronunci..."

San Girolamo

“... l'ansia del paziente viene ridotta, nelle situazioni di incertezza, dal semplice colloquio, anche se non è

conclusivo."

Anonimo

La semplice disponibilità ad ascoltare il paziente rappresenta il primo passo per una corretta comunicazione verbale, e pronunciare parole semplici in tono comprensivo di per sé riduce lo stato ansioso e crea un clima proattivo alla soluzione dei problemi. Tutto questo spesso è utile, ma non sempre è sufficiente. Diversi autori si interrogano sui con- 
don't tell; (2) tell if asked; (3) ask to tell; (4) always tell.

1. Don't tell: The view of the radiologist as the doctor's doctor has been widely overcome, as has that of radiologists choosing this specialty because they do not feel comfortable with having a direct relationship with patients [43]. Some draw attention to the danger of communicating incorrect, specifically false-positive, information as a result of being overeager to inform [17]. Roy Filly warns against providing patients with too much information [44], stating that $10 \%$ of obstetrical sonograms contain apparent foetal abnormalities, which may even be interpreted as markers for Down syndrome but which are ultimately of no consequence. Sharing one's doubts with the patient would contribute, according to Filly, to exaggerated and unjustified anxiety. On the other hand, not telling the patient would be even more serious according to the US and Italian Codes of Ethics. It is clear that the operator must have the skill to explain doubt and grade its severity, reducing anxiety in the case of a limited doubt.

2. Tell if asked: This is no longer an option but a duty. On the other hand, who better than the radiologist understands the images and is able to explain them to the patient? The radiologist knows the indications, limitations, risks and implications of imaging better than the clinician does [45]. If the radiologist fails to seize the opportunity to interact with the patient, overall control of the patient will be lost; today, in fact, it is not unusual for the patient not to know that the radiologist is a doctor, and they are able to distinguish radiology technicians from radiologists. There is no doubt that one of the most promising fields for investment in the future is training radiologists to communicate directly. The Italian Code of Ethics [13], as with the US one [46], is ultimately clear about the fact that the patient is entitled to know everything about his or her health and therefore "must" be told whenever he or she asks.

3. Ask to tell: Some people who are reluctant to ask or are not used to asking or have limited knowledge of the language - often elderly or foreign patients - might fail to ask for information about their tests. In these cases, medical personnel should be instructed to ask the patients if the information received is exhaustive or if they would like more details on their tests and test results. Such a proactive attitude would be extremely convenient if it translated into useful information and actions, especially in the event of findings requiring further diagnostic tests or specialist consultations, or in situations that necessitate monitoring. In these cases, the radiologist can arrange appointments with specialists, if the patients agree, or make appointments for the follow-up examinations. Provision of this service would require specific time slots. tenuti e sul "se dire", "quando dire", "come dire". Smith e Gunderman [42] argomentano il problema discutendo in quattro livelli: (1) non dire; (2) dire su richiesta; (3) domandare se ci sono richieste e poi dire; (4) dire sempre.

1. La visione del radiologo dottore dei dottori è oggi ampiamente superata, così come la posizione del medico che sceglie la specialità radiologia in quanto non desidera o non ritiene di avere la predisposizione a rapportarsi direttamente con il paziente [43]. Alcuni pongono l'attenzione sul pericolo, nell'ansia di informare, di trasmettere informazioni sbagliate, segnatamente false positive [17]. Roy Filly pone un caveat sul fornire eccessive informazioni alle pazienti [44] sostenendo che il 10\% delle ecografie ostetriche contiene anormalità apparenti, che possono essere interpretate anche come markers di sindromi di Down, ma che alla fine si rilevano inconsistenti. Anticipare all'interessata i dubbi contribuirebbe, a detta di Filly, un'esagerata e immotivata ansia. D'altra parte il non informare sarebbe in questi casi, in relazione al codice etico americano e italiano, ancora più grave. $\grave{E}$ chiaro che l'operatore deve avere le capacità per esporre il dubbio e per graduarne l'eventuale severità, smorzando l'ansia in caso di dubbio limitato.

2. "Dire su richiesta" non è più un'opzione, ma è diventato un dovere. D'altra parte chi più del radiologo conosce le immagini e può spiegarle al paziente? Il radiologo conosce le indicazioni, i limiti, nonché i rischi e le implicazioni dell'imaging più del clinico [45]. Se il radiologo non comprende le opportunità di interagire con il paziente in tale contesto perderà il totale controllo dei pazienti; oggi, infatti, non è inusuale che il paziente non sappia neppure che il radiologo sia un medico o non è in grado di distinguere il tecnico di radiologia dal medico. Non c'è dubbio che uno dei più promettenti campi di investimento del futuro sia l'addestramento del radiologo alla comunicazione diretta. Il codice etico italiano [13] così come quello americano [46] sono, in ultima analisi, chiari sul fatto che il paziente abbia diritto di conoscere tutto quello che è inerente alla propria salute e quindi che il paziente debba essere informato qualora lo richieda.

3. Alcune persone per scarsa propensione a chiedere, oppure per scarsa abitudine o per modesta o incompleta conoscenza della lingua, quindi spesso anziani o stranieri, potrebbero non richiedere informazioni circa le indagini di proprio interesse. In tali casi dovrebbe essere programmata la disponibilità del personale medico a richiedere agli interessati se le informazioni ottenute sono esaustive oppure se desiderano conoscere dettagli sulle loro indagini e sugli esiti relativi. Tale atteggiamento propositivo sarebbe estremamente conveniente se si traducesse con informazioni e atti utili alle persone soprattutto in caso di indagini positive che richiedano ulteriori accertamenti o visite specialistiche, oppure che presentino situazioni da controllare nel tempo. In questi casi il radiologo può provvedere a fornire gli appuntamenti con $i$ colleghi specialisti, se le persone condividono i suggerimenti, oppure fornire gli appuntamenti per le indagini 
There would be no increase in costs but, instead, savings resulting from more efficient management of healthcare by reducing idle time, as well as benefits not only for the patients, who might feel overwhelmed by the complexity of the healthcare system, but for all of society. Ragavendra et al. [23] report that the time spent informing the patient of normal results is on average less than $2 \mathrm{~min}$. In the case of minor abnormalities, it is on average less than 5 min, whereas in the case of significant abnormalities, it takes more than $8 \mathrm{~min}$. Although we can consider delegating to nonmedical professionals the task of communicating normal results, it is necessarily the radiologist who must communicate complex abnormalities or neoplastic diagnoses. The existing practice in some breast imaging services of employing psychologists is deleterious, as a psychologist knows nothing or very little about the disease, the case at hand or the next steps to be taken. The radiologist cannot delegate his duties to others.

4. Always tell: Gradually, it appears clear that we might as well always tell the patient, even if from a psychological point of view patients have to be given the impression that the request for information actually came from them. This would eliminate the risk of breaches in communication and any problems connected to the failure to communicate. After all, informing the patient is already the rule when his or her life is in immediate danger: what is the difference if the danger is deferred? This position is in line with that of the Italian Society of Medical Radiology (SIRM) [47] and the guidelines of the American College of Radiology (ACR) that, while not indicating this behaviour as compulsory, suggest that it is desirable. In fact, in 1999, the ACR guidelines [48] introduced the concept of direct communication with the patient, and in the 2005 review, the radiologist's ethical responsibility to communicate the test results directly to the selfreferred patient was added, and in any case, whenever the patient's life is at risk. In this context, there is, however, some cultural divide between the scientific societies and the needs of people in a changing world.

Nonetheless, communicating verbally with the patient is not easy, especially in the case of an abnormality.

There are three main situations in which physicians need to be prepared to communicate findings verbally to patients in a clear and not counterproductive manner: incidental findings, situations of risk and the presence of severe disease (especially if neoplastic).

Incidental findings

These have become increasingly common and are in most cases absolutely benign. The main goal is to reassure the pa- di controllo di propria competenza. Tale servizio richiederebbe la previsione di spazi temporali appositi. Non si tratterebbe di un aggravio di costi, ma in realtà di un risparmio per una gestione sanitaria più efficiente senza tempi morti, e di un guadagno non solo per i pazienti che, spaesati, potrebbero perdersi nei meandri della complessità sanitaria, ma per tutta la società. Raganvedra et al. [23] riportano che il periodo di tempo necessario per informare il paziente di risultati normali è mediamente inferiore a due minuti. In caso di problematiche modeste il tempo sarebbe mediamente inferiore a 5 minuti, mentre in caso di problematiche maggiori intorno agli

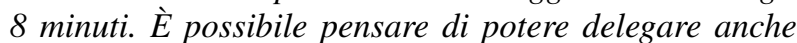
del personale non medico per fornire informazioni sulla normalità delle indagini, ma deve essere delegato il radiologo per problematiche complesse o per riferire diagnosi neoplastiche. La pratica esistente in alcuni servizi di senologia di impiegare psicologi è deleteria perché lo psicologo nulla sa o poco conosce sulla malattia e sul caso specifico e su quello che seguirà. Il radiologo non può demandare ad altri le proprie responsabilità.

4. Passo dopo passo si giunge alla conclusione che tanto vale dire in ogni caso, anche se, da un punto di vista psicologico, è necessario dare l'impressione agli interessati che la richiesta scaturisca motu proprio da loro stessi. Questo eliminerebbe il rischio di mancate comunicazioni e di problematiche legate alle mancate comunicazioni. In fin dei conti informare il paziente è già la regola quando la sua vita è in pericolo immediato, che cosa cambia se il pericolo è più dilazionato? Tale posizione non contrasta con quella della Società Italiana di Radiologia Medica (SIRM) [47], né con le linee guida dell'American College of Radiology (ACR) che peraltro non indicano categoricamente come obbligatorio questo comportamento, ma lasciano intendere l'auspicabilità. L'ACR infatti introduce nel 1999 [48] il concetto di "direct communication to the patient"; nella revisione del 2005 ACR introduce il concetto della responsabilità etica del radiologo nella comunicazione diretta del risultato delle indagini al paziente self referred e in ogni caso quando sia a repentaglio la vita del paziente. In questo ambito va rimarcato, comunque, un certo ritardo culturale delle Società scientifiche rispetto alle esigenze della società in evoluzione.

In ogni caso non è affatto banale comunicare verbalmente con il paziente soprattutto in caso di comunicazione di anormalità.

Esistono tre situazioni principali nelle quali occorre essere preparati per comunicare verbalmente in modo chiaro e non controproducente ai pazienti: $i$ reperti incidentali, situazioni di rischio, e la presenza di una patologia grave (in particolare neoplastica).

Reperti incidentali

Oggi sempre più comuni e per la maggior parte assolutamente benigni. L'obiettivo principale è quello di tranquil- 
tient. We need to know the precise statistical probability of malignancy of an incidental finding. Usually it is so low as not to warrant further investigation, even though increasingly defensive medicine would require follow-up at close intervals without rational bases. Despite the lack of guidelines on the subject, which we hope will be developed in the near future, it is clear that the patients need to be given the most up-to-date information so that they will ask for follow-up tests themselves in a calm and rational manner. Frightening the patient is not ethical and is generally counterproductive.

\section{Situations of risk}

Similar considerations hold true for the notion of risk. We often face this problem in the context of screening or when examining patients with a history of cancer (risk of recurrence, metastasis, etc.). The perception of risk is the product of its quantification through a numerical estimation of likelihood and the emotional component that each of us subjectively associates with risk. Knowledge, trust in the doctor and health system, controllability and willingness are all aspects that help reduce the negative perception of risk; in contrast, highlighting the catastrophic potential, previous negative examples and inappropriate media messages will negatively affect the awareness of risk. We therefore need to frame the situation positively for the patient (the greater likelihood of not developing severe conditions or complications, the fact that monitoring the complication will help to detect it early on). Often the concept of risk is not clear even to the operator. This may result in excessive alarmism, which is counterproductive and tends to drive the patient away rather than ensure adherence to all the necessary tests and investigations.

\section{Bad news}

Communicating bad news requires special skill and sensitivity. The severity of bad news is directly proportional to the gap between the real situation (objective reality) and perceived situation (subjective reality); on the other hand, the majority of individuals want to be told [49-51]. The operator must be motivated and prepared, know how to start (breaking the ice), inform (giving hope), be able to provide psychological support and outline a plan of action capable of overcoming the patient's psychological confusion, and finally be able to close the consultation stating clearly what the next steps are. The radiologist must know how to use simple language, not give all the information at once but leave room for questions and use euphemisms to prepare the patient and lessen the impact of the news. The radiologist must also inform the patient that treatment will involve a team of professionals; in this case, it is useful to use the lizzare. È necessario conoscere in modo preciso la probabilità statistica che quel reperto incidentale abbia di non essere benigno. Di solito è così bassa che non meriterebbe controlli, che la medicina sempre più difensiva richiede anche in tempi eccessivamente ravvicinati e in modalità non razionale. Pur mancando spesso le linee guida, auspicabili in un prossimo futuro, vanno fatte presenti le informazioni più recenti su quell'argomento, così che il paziente stesso richiederà il controllo in maniera serena. Spaventare il paziente non è corretto e generalmente controproducente.

\section{Situazioni di rischio}

Un discorso analogo va fatto per il rischio. Spesso ci si imbatte in questo tipo di problematica nelle indagini di screening, o su pazienti già risultati affetti da neoplasia (rischio di recidive, di metastasi ecc.). La percezione del rischio è il prodotto della sua quantificazione attraverso la stima numerica delle probabilità e della componente emozionale che ciascuno in modo soggettivo associa al rischio. La conoscenza del problema da parte della persona, la fiducia verso il medico e nelle istituzioni, la controllabilità e volontarietà sono aspetti che riducono la percezione negativa del rischio, mentre l'esaltazione del potenziale catastrofico, di precedenti esempi negativi, l'incertezza e i messaggi mediatici incongrui peggiorano la consapevolezza del rischio. È necessario quindi prospettare sempre l'aspetto positivo (il cosiddetto framing positivo o quadro di presentazione) per il paziente (la migliore probabilità di non incorrere in situazioni o complicanze gravi, il fatto che essendo sotto controllo la complicazione sarà colta in tempo), e non quello negativo. L'operatore stesso spesso non ha ben chiaro il concetto di rischio e potrebbe creare un eccessivo allarmismo, che come nel caso precedente si rivela controproducente, e tende ad allontanare l'interessato, piuttosto che farlo propendere per i controlli del caso.

\section{Cattive notizie}

Comunicare cattive notizie richiede un'attenzione e delle capacità particolari. La notizia è tanto più cattiva quanto maggiore è la differenza tra la situazione reale (realtà oggettiva) e la percezione della realtà (realtà soggettiva), d'altra parte, come sopradetto, la maggior parte delle persone vuol sapere [49-51]. L'operatore deve essere motivato e preparato, sapere iniziare (rompere il ghiaccio), informare (mantenendo viva la speranza), sapere fornire supporto psicologico e predisporre un piano di azione che consenta di superare la confusione psicologica dell'interessato e infine sapere concludere rendendosi disponibile per $i$ successivi passi. Il radiologo deve sapere usare un linguaggio semplice, non dare le notizie tutte in una volta ma lasciare spazio per le domande, impiegare eufemismi per preparare e attenuare l'impatto. Il radiologo inoltre deve fare presente che la cura del paziente coinvolge più professionisti; in questo caso è utile utilizzare l'esempio della staffetta dove il pa- 
example of the relay race in which the patient is the baton being passed from hand to hand among the race participants (the different professionals) and never dropped.

\section{How to communicate}

“Mrs. X, I don't like what I saw... ...I would have wanted the earth to open up and swallow me! It's been two years now and my daughter is fine, and I want you to know that the fact that she was there helped to reduce my fears. Thank you for your promptness in replying to my questions and for having helped me find a haematologist. Thank you" (letter from a patient)

Some practical aspects have already been mentioned here, but the matter is complex and still evolving. According to Ortega and García, this issue is still unresolved [52]. The main aspects to be considered are setting, time and training. Setting and time have already been mentioned; verbal communication, especially of information regarding major abnormalities, cannot take place in a corridor or waiting room or take only $30 \mathrm{sec}$. The setting must be appropriate, with room for the radiologist and patient to sit down. Sufficient time must be allocated to the encounter. This may be in conflict with both the structure of imaging facilities - where there are few quiet areas and none of them devoted to consultations - and with department productivity. On the other hand, effective communication is an essential component of high-quality healthcare, so hospital managers need to be aware of the additional time required to give due communication in the organisation of work and productivity.

In her paper "Communication: the key to improve patient care" [53], Peggy J. Fritzsche wrote: “... if your patients are like mine, you know they want to learn the results of imaging tests immediately after the examination. If there is miscommunication here, who is failing? The patient? The radiologist"? It is clear that even if both are failing, communication is the responsibility of the physician, who must be prepared for the task. Communication is, in fact, a circular process, with an emitter (the physician), a receiver (the patient), a means (speech and body language) and a feedback mechanism for checking reception. The process is completed with the feedback mechanisms (Do you understand? Is it all clear? What shall we do?). We could discuss at length the various aspects of communication through body language, a complementary yet essential component of verbal communication - a comforting hand, eye contact to convey honesty and truthfulness, but also looking at your watch when you are in a hurry or at your hand on the door handle when you ziente corrisponde al testimone che viene passato di mano in mano dai vari componenti la staffetta ( $i$ diversi professionisti) e mai lasciato cadere.

\section{Come comunicare}

"Signora, quello che ho visto, non mi è piaciuto per niente ... Avrei voluto che una voragine si aprisse sotto $i$ miei piedi e sprofondarci dentro! Sono ormai passati due anni e mia figlia sta bene e io desidero dirle che il fatto che ci fosse lei con me, in quel momento mi ha fatto avere un po' meno paura. Grazie della sollecitudine nelle sue risposte e nell'aver facilitato la strada verso l'ematologo.

Grazie"

(lettera di una paziente)

Si è già fatto cenno su alcuni aspetti pratici, ma il problema è tutt'altro che semplice e il processo è del tutto in evoluzione, per Ortega e García si tratta di un capitolo non ancora risolto [52]. Gli aspetti fondamentali del problema sono tre: il contesto, il tempo, la formazione. Sul contesto e sul tempo si è già accennato; la comunicazione verbale, specie per le informazioni di anormalità importanti, non può avvenire in un corridoio o in una sala d'aspetto. Non può neppure avvenire in 30 secondi (mordi e fuggi). L'ambiente deve essere idoneo e permettere agli interessati e al radiologo di stare seduti. Il tempo concesso al colloquio deve essere sufficiente. Oggi questo crea conflitto sia con la struttura del servizio che prevede pochi spazi tranquilli e nessuno deputato ad hoc, che dovrà invece essere previsto per il futuro, sia con la produttività. D'altra parte una comunicazione efficace è una componente essenziale di una cura di alta qualità della salute del paziente e quindi il manager dovrà tenere conto del tempo necessario per espletare la "dovuta" comunicazione nell'organizzazione del dipartimento e della produttività .

Peggy J. Fritzsche scrisse in un suo lavoro "Communication: the key to improve patient care" [53]: "se i tuoi pazienti sono come i miei, tu sai che vogliono sapere il risultato dell'esame. Se a questo punto nasce un'incomprensione di chi è la colpa? Del medico? Del paziente? Di entrambi?". È chiaro che se la colpa può essere di entrambi la responsabilità è però del medico che deve essere preparato per quel tipo di compito. La comunicazione è infatti un processo circolare con un'emittente (il medico), un ricevente (il paziente), un mezzo (la parola, ma anche il linguaggio del corpo), e un meccanismo di feed-back per controllo dell'avvenuta ricezione. Il processo si completa solamente con il feed-back (ha capito? ha capito bene? cosa facciamo?). Si potrebbe parlare a lungo degli aspetti relativi alla comunicazione attraverso il linguaggio del corpo che rappresenta una componente complementare, ma essenziale della comunicazione verbale, dalla mano che conforta e accarezza, allo sguardo diretto che conferisce veridicità e sincerità alle parole, ma anche allo sguardo all'orologio che indica fret- 
want to put an end to the conversation. These are all aspects of basic communication psychology that reinforce the conviction that the operators require adequate training.

In 2006, Ortega and García found that the majority of radiologists reported insufficient training in communication skills [52]. On the other hand, in 2009, Sasson et al. reported a widespread interest in specific training in communication skills among US radiologists [54]. Thus, the need for training in communication skills has been felt for at least a decade in developed countries.

In 2000, the American Board of Medical Specialties [55] defined six main competencies that should be common to all physicians, one of them being interpersonal and communication skills. In 2005, the Official Gazette of the Italian Republic published the new statute of medical residency schools [56], which for the first time feature communication as a taught subject. The new standards for professional accreditation in the United States are published on the Internet: (1) The National Board of Medical Examiners, Steps 2 and 5 [57]; (2) The Accreditation Council for Graduate Medical Education [58], where verbal communication is an established component. In the context of communication skills in diagnostic imaging, the standards provide a list of required skills: sensitivity, courtesy, compassion, appropriateness, honesty and openness. In addition, they give the following ten rules:

1. Take a few minutes to introduce and present the problem.

2. Shake hands and address the patient with respect.

3. Maintain eye contact.

4. Touch the patient, as no words can substitute.

5. Find out if the patient has been waiting and acknowledge and justify the delay.

6. Briefly obtain the patient's history.

7. Explain the procedures and tests in language the patient can understand.

8. Answer questions and admit to "not knowing" an answer.

9. Listen carefully.

10. Take the opportunity to encourage the patient.

Achieving adequate preparation requires only modest theoretical bases but a long period of practical training [59, 60]. For practical training, the use of simulations has been suggested in which volunteer patients or ex-patients act as teachers and assessors [61]. Also acting as teachers on these programmes are patients who survived breast cancer, and awkward and delicate conversations are carried out that allow one to assess the operators' communicative competence. The encounters are recorded, reviewed and commented upon. In these simulations, the radiology resident reads the results of the diagnostic test, writes up the report and communicates the result to the patient. At the university at tolosità o alla mano sulla maniglia della porta che egualmente vuole troncare la conversazione. Sono tutti aspetti di psicologia elementare della comunicazione che ci aiutano a rafforzare il convincimento che sia necessaria una robusta formazione degli operatori.

Ortega e García nel 2006 affermavano che la maggior parte dei radiologi riportava una preparazione insufficiente nell'ambito dei processi di comunicazione [52]. D'altra parte Sasson et al nel 2009 riportano il comune sentire di un interesse diffuso dell'ambiente radiologico USA per una specifica preparazione in comunicazione [54]. È quindi da almeno un decennio che nei paesi occidentali nasce la necessità di formare in comunicazione.

L'American Board of Medical Specialties [55] nel 2000 defini 6 principali competenze comuni a tutti i medici. Fra esse compare la capacità di comunicazione (interpersonal and communication skills). Nel 2005 in Italia viene pubblicata sulla Gazzetta Ufficiale il nuovo statuto delle scuole di specializzazione [56], dove per la prima volta viene previsto l'insegnamento della comunicazione. Su internet è possibile prendere visione dei nuovi standard di accertamento professionale e post-laurea negli Stati Uniti: 1. The National Board of Medical Examinery, Step 2 e 5 [57]; 2. The Accreditation Council for Graduate Medical Education [58] dove ormai la comunicazione verbale rappresenta un elemento basilare. Nell'ambito dei processi comunicativi in radiologia vengono indicate le capacità necessarie: sensibilità, cortesia, capacità di creare empatia/partecipazione emotiva, appropriatezza del comportamento, onestà, disponibilità e viene enunciato il Decalogo:

1. Dedicare alcuni minuti per presentare e introdurre il problema.

2. Dare la mano e utilizzare appellativi di rispetto.

3. Guardare negli occhi.

4. Cercare il contatto fisico che supera le parole.

5. Riconoscere il tempo di eventuale attesa (ritardo) e giustificarlo.

6. Raccogliere brevemente la storia clinica.

7. Spiegare le procedure e il test diagnostico in modo comprensibile.

8. Rispondere alle domande e ammettere di non sapere.

9. Sapere ascoltare con attenzione.

10. Cogliere l'opportunità per incoraggiare.

Per giungere ad un'adeguata preparazione occorrono basi teoriche modeste, ma un lungo training pratico [59, 60]. Per quanto riguarda la preparazione pratica si suggeriscono delle simulazioni nelle quali pazienti o ex-pazienti volontari fungono da veri e propri insegnanti e valutatori [61]. In questi programmi si prestano al ruolo di insegnanti pazienti sopravvissute a neoplasie mammarie, e vengono messe in essere conversazioni difficili e scabrose, che permettano di identificare il grado di capacità comunicativa degli operatori; gli incontri vengono registrati, rivisti e commentati. In queste simulazioni lo specializzando in radiologia legge l'esito del test diagnostico, lo referta e comunica il risultato al paziente. Nella scuola di specializzazione 
which I am employed, radiology residents training in breast imaging observe the radiologist during verbal communication of the diagnosis to the patient, and then, once they have gained sufficient autonomy, conduct the encounter themselves in the presence of a tutor. In the event of a condition requiring therapeutic intervention, these conversations will also include a treatment-planning stage, as suggested by Lown et al. [61].

Acquiring these communication skills is neither obvious nor banal, and very often radiology residents and young radiologists do not feel comfortable with the task. These responsibilities, which are indispensable for adding clinical value to radiology, are a source of stress and often cause detachment and withdrawal from the discipline (burnout), or at least from those activities requiring direct contact with the patient, and especially breast imaging [61]. Education and training in communication would, however, help reduce stress and allow more responsibilities to be taken on [14, 17, 30]. It is therefore clear that we need trainers prepared to devise adequate curricula to teach and assess the resident's individual skills.

Connected to this there is also a need, as Pasquale Marano suggested [1], to create a cultural background that gives the radiologist a partly humanistic education and a more holistic view of patients' problems and to adopt a more practical and tutorial approach to teaching. This process should also involve health system administrators and politicians at a local and national level to communicate the idea that medicine is changing and becoming more personalised and targeted to the needs and dignity of the individual.

Acknowledgements I thank Dr. Paola Clauser for her help in writing the final draft of the manuscript and the bibliography. in radiologia della mia università lo specializzando durante il training senologico affianca lo strutturato durante la comunicazione verbale della diagnosi, per poi condurre lui stesso in prima persona la conversazione in presenza del tutor, una volta acquisita una sufficiente autonomia. Durante queste conversazioni viene anche fatto il planning quando si tratti di patologia che richieda un intervento terapeutico, come suggerito da Lown et al. [61].

L'acquisizione di queste capacità comunicative non è né scontata né banale, e molto spesso mette in difficoltà gli specializzandi e i giovani radiologi. L'assunzione di tali responsabilità, indispensabili per dare valore clinico alla radiologia, sono fonte di stress e spesso provocano il distacco dalla disciplina (burn out) o perlomeno da quelle attività della disciplina che sono a più diretto contatto con il paziente, specialmente la diagnostica senologica [61].

L'insegnamento però della comunicazione ridurrebbe lo stress e consentirebbe l'assunzione di maggiori responsabilità $[14,17,30]$. È quindi evidente il bisogno di uno staff preparato per confezionare curricula adeguati proprio per insegnare (formare per formare), e per valutare le capacità individuali degli specializzandi.

Dietro tutto questo sta anche, come ha suggerito Pasquale Marano [1], avere e creare un back-ground culturale che conferisca al radiologo una preparazione anche umanistica e una visione più olistica delle problematiche dei pazienti, nonché modificare le modalità di insegnamento verso formule più pratiche e tutoriali. In tale processo vanno coinvolti anche gli amministratori del sistema nonché i politici a livello locale e nazionale per fare comprendere che la medicina sta evolvendo verso modalità più personalizzate e ritagliate sui bisogni e sulla dignità della persona.

Ringraziamenti Si ringrazia la dottoressa Paola Clauser per l'assistenza alla stesura definitiva del lavoro e della bibliografia.

\section{Conflict of interest None}

\section{References/Bibliografia}

1. Marano P (2008) Education and professionalism of the radiologist in a constantly evolving society. Radiol Med 113:307-318

2. Hall FM (2009) The radiology report of the future. Radiology 251:313-316

3. Glazer GM, Ruiz-Wibbelsmann JA (2011) The invisible radiologist. Radiology 258:18-22

4. Censis - Forum per la ricerca biomedica (Roma 5 luglio 2007) "Salute e comunicazione 2007 - Fiducia, dialogo, scelta". Available at: http://www. censis.it. (Last access January 2012)
5. American College of Radiology (2003) ACR Breast Imaging Reporting and Data System (BI-RADS). Available at: http://www.acr.org. (Last access January 2012)

6. Bosniak MA (1997) Diagnosis and management of patients with complicated cystic lesions of the kidney. AJR Am J Roentgenol 169:819-821

7. Tamburrini O (2011) Informare/ comunicare in radiologia. Il Radiologo $1: 24-25$
8. Gawande A (2010) Special lecture: "Real reform: facing the complexity of health care". RSNA, Chicago, 29 November 2010

9. Gawande A (2009) The checklist manifesto. How to get things right. Metropolitan Books, New York

10. Berlin L (1997) Radiology reports. AJR Am J Roentgenol 169:943-946

11. Mayo WJ (1910) Speech to graduating class of doctors at Rush Medical College, Chicago. Available at: http:// www.clinicguide.org. (Last access January 2012) 
12. Sherman RS (1966) Whom do we serve? Radiology 87:147-148

13. Codice di deontologia medica (3 ottobre 1998) http://portale.fnomceo.it/ PortaleFnomceo/home.2puntOT

14. Berlin L (1977) The radiologist: doctor's doctor or patient's doctor. AJR Am J Roentgenol 128:702

15. The Mammography Quality Standards Act MQSA (27 October 1992) Public Law 102-539. Available at: http:// www.fda.gov/MedicalDevices/ DeviceRegulationandGuidance/ GuidanceDocuments/ucm094373.htm. (Last access January 2012)

16. Physician Insurers Association of America and American College of Radiology (1997) Practice standards claims survey. Physician Insurers association of America, Rockville

17. Berlin L (2007) Communicating results of all radiologic examinations directly to patients: has the time come? AJR Am J Roentgenol 189:1275-1282

18. Jordan H (2000) No such thing as a bad day. Longstreet Press, Atlanta GA

19. Kolata G (2005) Sick and scared, and waiting, waiting, waiting. The New York Times, 20 August 2005

20. Levitski DB, Frank MS, Richardson ML et al (1993) How should radiologists reply when patients ask about their diagnoses? A survey of radiologists' and clinicians' preferences. AJR Am J Roentgenol 161:433-436

21. Schreiber MH, Leonard M Jr, Rieniets CY (1995) Disclosure of imaging findings to patients directly by radiologists: survey of patients' preferences. AJR Am J Roentgenol 165:467-469

22. Schreiber MH (1996) Direct disclosure by radiologists of imaging findings to patients: a survey of radiologists and medical staff members. AJR Am J Roentgenol 167:1091-1093

23. Ragavendra N, Laifer-Narin SL, Melany ML et al (1998) Disclosure of results of sonographic examinations to patients by sonologist. AJR Am J Roentgenol 170:1423-1425

24. Liu S, Basset LW, Sayre J (1994) Women's attitudes about receiving mammographic results directly from radiologists. Radiology 193:783-786

25. Allen SM, Petrisek AC, Laliberte LL (2001) Problems in doctor-patient communication: the case of younger women with breast cancer. Critical Public Health 11:39-58
26. Molenaar S, Sprangers MA, Rutgers EJ et al (2001) Decision support for patients with early-stage breast cancer: effects of an interactive breast cancer CDROM on treatment decision, satisfaction and quality of life. J Clin Oncol 19:1676-1687

27. Basu PA, Ruiz-Wibbelsmann J, Spielman SB et al (2011) Creating a patient-centered imaging service: determining what patients want. AJR Am J Roentgenol 196:605-610

28. Doctor News. Available at: http://www. doctor33.it/la-vera-emergenza-egravenella-comunicazione/politica-e-sanita/ news-5037.html. (Last access January 2012)

29. Lorch H, Scherer P (2007) Disclosure of diagnosis in ambulatory radiology practice: expectations of patients and referring physicians. Rofo Fortschr Geb Rontgenstr Neuen Bildgeb Verfahr 179:1043-1047

30. Berlin L (2009) Communicating results of all outpatient radiologic examinations directly to the patients: the time has come. AJR Am J Roentgenol 192:571-573

31. Williams v Le, 662 S.E. $2 d 73$ (Va 2008) www.vamedmal.com/.../virginiaradiologist-cannot-blame-internist-f.

32. Schwinger HN (1990) Liability problems in radiology communications exist. ACR Bulletin 46:33

33. Levinson W (1994) Physician-patient communication. A key to malpractice prevention. JAMA 272:1619-1620

34. Fernald DH, Pace WD, Harris DM et al (2004) Event reporting to a primary care patient safety reporting system: a report from the ASIPS collaborative. Ann Fam Med 2:327-332

35. Fileni A (2011) Come ragionano i giudici nel valutare la colpa medica. Il Radiologo 1:52-53

36. Vincent C, Young M, Phillips A (1994) Why do people sue doctors? A study of patients and relatives taking legal action. Lancet 343:1609-1613

37. Popper KR (2000) La scienza e i suoi nemici. Armando Editore, Roma

38. Goddard P, Leslie A, Jones A et al (2001) Error in radiology. Br J Radiol 74:949-951

39. Fitzgerald R (2001) Error in radiology. Clin Radiol 56:938-946

40. Gunderman RB, Burdick EJ (2007) Error and opportunity. AJR Am J Roentgenol 188:901-903

41. Damasio AR (1994) Descartes' error: emotion, reason, and the human brain. Putnam, New York
42. Smith JN, Gunderman RB (2010) Should we inform patients of radiology results? Radiology 255:317-321

43. Song HH, Park SH, Shinn KS (1993) Radiologists' responses to patients' inquiries about imaging results. A pilot study on opinions of various groups. Invest Radiol 28:1043-1048

44. Filly RA (2000) Obstetrical sonography: the best way to terrify a pregnant woman. J Ultrasound Med $19: 1-5$

45. Gunderman RB (2001) Patient communication: what to teach radiology residents. AJR Am J Roentgenol 177:41-43

46. American medical Association's Code of Medical Ethics (2001). Available at: http://www.ama-assn.org/ama/pub/ physician-resources/medical-ethics/ code-medical-ethics.page. (Last access January 2012)

47. Società italiana di Radiologia Medica (SIRM): Linee Guida. Available at: http://www.sirm.org/it/linee-guida. (Last access January 2012)

48. ACR practice guideline for communication of diagnostic imaging findings (1991, last revised: 2010). Available at: http://www.acr.org/ secondarymainmenucategories/quality_ safety/guidelines/dx/comm_diag_rad. aspx. (Last access January 2012)

49. Lind DD (1989) The doctor as patient advocate. JAMA 262:3269

50. Sell L, Devlin B, Bourke SJ et al (1993) Communicating the diagnosis of lung cancer. Respir Med 87:61-63

51. Toscani F (1991) Is palliation "medicine"? Ethical and epistemological problems. J Palliat Care 7:33-37

52. Ortega D, García C (2006) Communication between radiologists and patients: an unsolved issue. J Am Coll Radiol 3:472-477

53. Fritzsche PJ (2005) Communication: the key to improve patient care. Radiology 234:13-14

54. Sasson JP, Zand T, Lown BA (2008) Communication in the diagnostic mammography suite: implications for practice and training. Acad Radiol $15: 417-424$

55. American Board of Medical Specialties. Available at: http://www. abms.org. (Last access January 2012) 
56. Decreto 1 agosto 2005, Riassetto delle Scuole di specializzazione di area sanitaria, Gazzetta Ufficiale Repubblica Italiana $\mathrm{n}^{\circ} 258,5$ novembre 2005 ,

Roma, supplemento ordinario $\mathrm{n}^{\circ} 176$

57. National Board of Medical Examiners. Available at: http://www.nbme.org.

Last access January 2012
58. Accreditation Council for Graduate Medical Education. Available at: http:// www.acgme.org. Last access January 2012

59. Makoul G (2001) Essential elements of communication in medical encounters: the Kalamazoo Consensus statement. Acad Med 76:390-393
60. Rider EA, Hinrichs MM, Lown BA (2006) A model for communication skills assessment across the undergraduate curriculum. Med Teach 28:e127-e134

61. Lown BA, Sasson JP, Hinrichs P (2008) Patient as partners in radiology education: an innovative approach to teaching and assessing patient-centered communication. Acad Radiol 15:425432 